\title{
Chvostek's sign: a video demonstration
}

\author{
Sadishkumar Kamalanathan, ${ }^{1}$ Karthik Balachandran, ${ }^{1}$ Girish Parthan, ${ }^{1}$ Abdoul Hamide ${ }^{2}$ \\ ${ }^{1}$ Department of Endocrinology, Jawaharlal Institute of Post Graduate Medical Education and Research, Puducherry, India \\ ${ }^{2}$ Department of Medicine, Jawaharlal Institute of Post Graduate Medical Education and Research (JIPMER), Pondicherry, India
}

Correspondence to Dr Sadishkumar Kamalanathan, sadishkk@gmail.com

\section{DESCRIPTION}

A 53-year-old lady was referred to the Endocrinology department of our institute for management of postsurgical metabolic complaints following near total thyroidectomy done elsewhere for obstructive nodular goitre 2 weeks back. She was started on thyroxine of $150 \mathrm{mcg}$ and calcium of $3 \mathrm{~g}$ in divided doses postoperatively. Her clinical evaluation showed her to have positive Chvostek's (video 1) and delayed Trousseau's sign. Her calcium was documented to be $1.4 \mathrm{mmol} / \mathrm{l}$ (normal range (NR) 2-2.5), phosphate $2.4 \mathrm{mmol} / \mathrm{l}$ (NR 0.8-1.5) and $\mathrm{iPTH} 0.5 \mathrm{pmol} / \mathrm{l}$ (NR 1.2-5.8). Her fT4 was 12.2 $\mathrm{pmol} / \mathrm{l}$ (NR 10.3-23.2) and thyroid stimulating hormone was $3.8 \mathrm{mIU} / 1$ (NR 0.5-4.5). Her biopsy was confirmed to be nodular goitre. Postsurgical hypothyroidism with hypoparathyroidism was diagnosed. She was additionally started on calcitriol $(0.25 \mathrm{mcg}$ twice daily) and calcium dose modified (2 $\mathrm{g}$ in divided doses) and soon her Chvostek's sign resolved. High doses of calcium may not be sufficient in the management of hypoparathyroidism and often requires addition of active vitamin $\mathrm{D}$.

Chvostek's sign was attributed initially to increased sensitivity of the facial nerve to mechanical stimuli in idiopathic epidemic tetany. ${ }^{1} 2$ Traditionally, it is elicited by tapping on the face at a point just anterior to the ear and just below the zygomatic bone. ${ }^{3}$ A positive response is represented by twitching of the ipsilateral facial muscles, suggesting neuromuscular excitability caused by hypocalcaemia. Although, classically described with hypocalcaemia due to hypoparathyroidism, it is also elicited in some young healthy children and alkalotic states as during vomiting and hyperventilation. It is very easy to test in clinical practice compared with Trousseau's sign and hence its clinical significance.

\section{Learning points}

A positive Chvostek's sign represents increased neuromuscular excitability caused by hypocalcaemia.

- It can be even elicited in some young healthy children and alkalotic states following vomiting and hyperventilation.

- Resolution of Chvostek's sign occurs with effective treatment of hypoparathyroidism with calcium and active vitamin D.

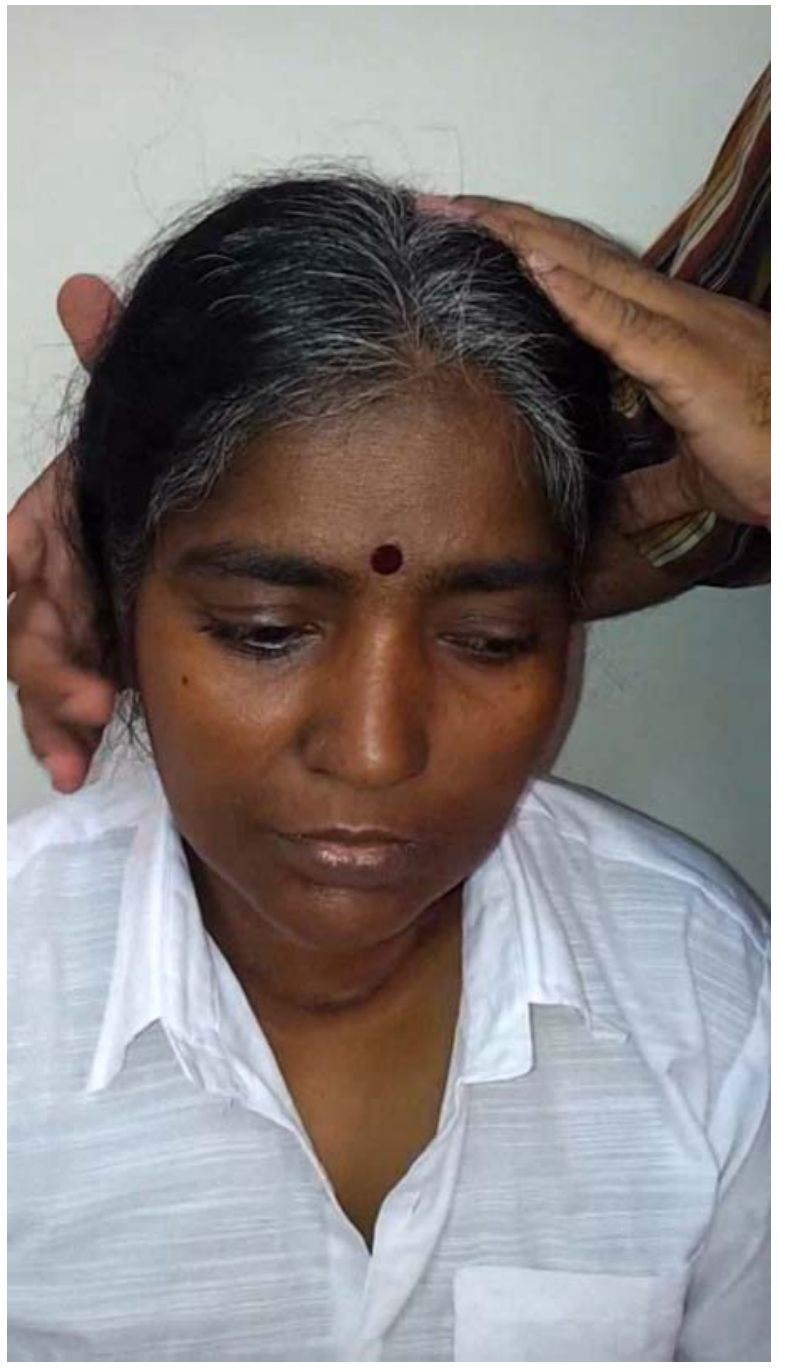

Video 1 Video clip demonstrating Chvostek's sign in post-thyroidectomy patient.

Competing interests None.

Patient consent Obtained.

\section{REFERENCES}

1. Krogh L, Wynne JM, Cywes S. The value of Chvostek's sign in tetany. S Afr Med J 1968:42:846-7.

2. Kugelberg E. The mechanism of chvostek's sign. AMA Arch Neurol Psychiatry 1951;65:511-17.

3. Hoffman E. The Chvostek sign; a clinical study. Am J Surg 1958;96:33-7. 


\section{BMJ Case Reports}

This pdf has been created automatically from the final edited text and images.

Copyright 2012 BMJ Publishing Group. All rights reserved. For permission to reuse any of this content visit http://group.bmj.com/group/rights-licensing/permissions.

BMJ Case Report Fellows may re-use this article for personal use and teaching without any further permission.

Please cite this article as follows (you will need to access the article online to obtain the date of publication).

Kamalanathan S, Balachandran K, Parthan G, Hamide A. Chvostek's sign: a video demonstration. BMJ Case Reports 2012;10.1136/bcr-2012-007098, Published XXX

Become a Fellow of BMJ Case Reports today and you can:

- Submit as many cases as you like

- Enjoy fast sympathetic peer review and rapid publication of accepted articles

- Access all the published articles

- Re-use any of the published material for personal use and teaching without further permission

For information on Institutional Fellowships contact consortiasales@bmjgroup.com

Visit casereports.bmj.com for more articles like this and to become a Fellow 